\title{
The ethics of genetic engineering
}

\author{
By Logan Townsend
}

Although still controversial, genetically modified foods have been grown and made commercially available for decades. More recently, and probably more controversially, various forms of human genetic modifications now exist. Basically, scientists alter the genetic makeup of a person, usually by injecting a virus that carries a particular gene. Once implanted, the virus will insert genes into the recipient's genome, thereby altering the recipient's DNA. This method could conceivably be used to 'fix' hereditary defects and genetic mutations, or for more superficial reasons.

It is important to appreciate that there are different types of human genetic engineering, including somatic and germline (1). Somatic engineering affects only the individual receiving treatment whereas germline engineering will affect the individual, their progeny, and all subsequent offspring. Simply put, genetic-engineering could alter a single person or their entire lineage.

Because others have the freedom to do what they want to their own bodies (hence cosmetic surgery, tattoos, and doctor assisted death), I suspect there are fewer objections to somatic engineering. The controversial crux of genetic-engineering probably comes from the manipulation of DNA in a way that will influence all subsequent offspring. Humans don't want strangers infringing upon their own rights...or genes; to paraphrase a classic line, your rights end at the beginning of my telomere.

There are many objections to human genetic-engineering, and one is that it is unnatural. Philosopher David Hume (2) said there is no word more ambiguous and equivocal than the definition of 'nature,' and if we cannot define 'natural' we cannot define 'unnatural.' John Stuart Mill (3) thought nature "...means the sum of all phenomena...including not only all that happens, but all that is capable of happening. Nature, then ... is a collec-

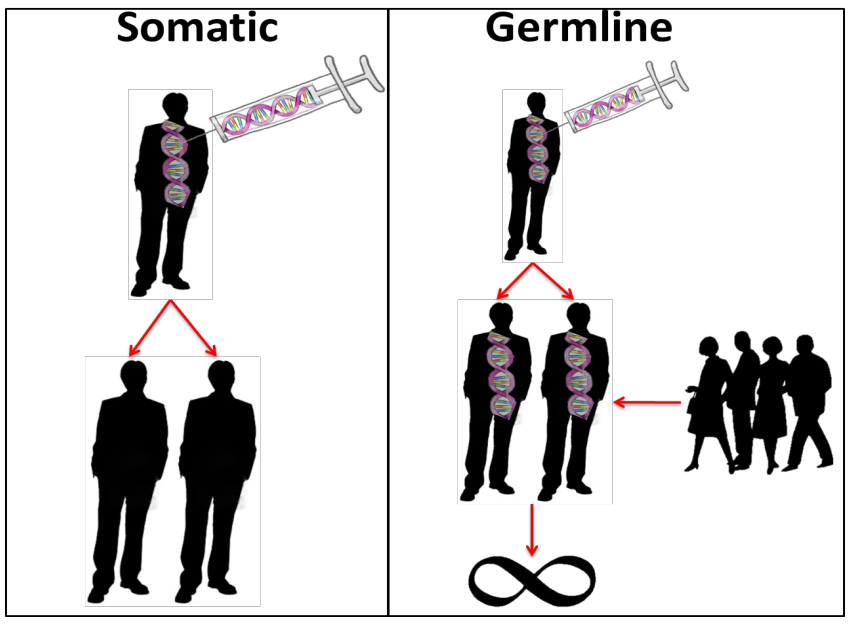

tive name for all facts, actual and possible." Similarly, Mark Sagoff (4) gives a more modern description of nature, "Everything in the universe. Everything technology produces has to be completely natural because it conforms to all of nature's laws and principles." By these definitions, genetic-engineering would certainly be natural.

But Anthony van der Schaaf (5) realizes that when people say 'unnatural' they could actually mean 'supernatural' and object that we are 'playing God'. However, even most theologians agree that God expresses himself in all forms of creation (6), which I would argue must include genetic-engineering. We could also take geneticengineering to be an expression of human free-will. Thus, genetic-engineering is either an expression of God's will or it is the result of God giving us free will (6), but either way bio-engineering wouldn't be violating God's will.

But maybe the best response to the God objection, coming from Van Der Schaaf (5), is that "humans do not possess the powers of God, so we are really only playing God." In other words, people aren't worried that we have 


\section{Health Science Inquiry}

\section{References}

1. Clapper R. Human Genetic Engineering: A Very Brief Introduction. online article. http://www. redorbit. com/news/science/1112819269/human-genetic-engineering-a-very-briefintroduction. 2013 Oct.

2. Hume D. A Treatise on Human Nature. In Raphael DD. (ed.) British Moralists, Book III. Indianapolis, US: Hackett; 1991.

3. Mill JS. Three Essays on Religion: Nature. In Golden O, Kilroe P. (eds.) Human Life and the Natural World: Readings in the History of Western Philosophy. Peterborough, Canada: Broadview Press; 1997.

4. Sagoff M. Genetic Engineering and the Concept of the Natural. In Eaglesham A, Pueppke S, Hardy R. (eds.) NABC Report 13. Ithaca, US: National Agricultural Biotechnology Council; 2001.

5. Vander Schaaf A. Frankenfood meets the gastronome: A philosophical analysis of some ontological and axiological aspects of the genetic modification of food [PhD thesis]. University of Guelph; 2010.

6. Vander Schaaf A. Frankenfood meets the gastronome: A philosophical analysis of some ontological and axiological aspects of the genetic modification of food [PhD thesis]. University of Guelph; 2010.

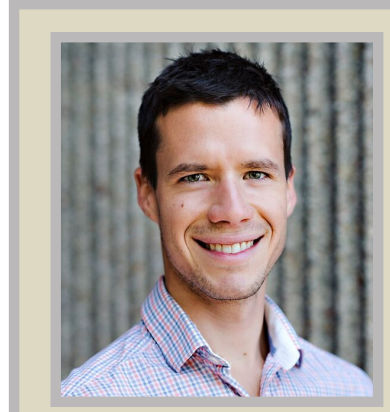

Logan Townsend

Logan is a first year PhD student at the University of Guelph. His research relates to metabolic contributors to the development of diabetes. Specifically he focuses on liver and adipose tissue and the effects of interleukin- 6 . In his spare time he enjoys rock climbing and mountain biking. 